\title{
Estimation of the Potential Eye and Tissue Donor Pool in an Australian Emergency Department
}

Short Running title: Improving eye and tissue donation in emergency

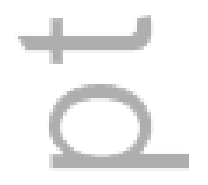

$=$

U

Authors:

Dr Damian Johnson MD, Bsc

$\infty$

Dr Martin Dutch

Emergency Physician and Medical Donation Specialist

BMedSci(Hons), MBBS(Hons), MPH\&TM, FACEM

A/Prof J onathan Knott MBBS PhD MClinEd FACEM

Emergency Medicine Research Unit - Royal Melbourne Hospital 300 Grattan Street, Parkville VIC 3050

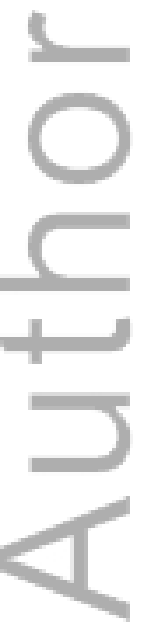

Martin.Dutch@mh.org.au

$+61413281864$

Royal Melbourne Hospital

300 Grattan Street, Parkville VIC 3050

Word Count: 2778

This is the author manuscript accepted for publication and has undergone full peer review but has not been through the copyediting, typesetting, pagination and proofreading process, which may lead to differences between this version and the Version of Record. Please cite this article as doi: $10.1111 / 1742-6723.12576$

This article is protected by copyright. All rights reserved. 


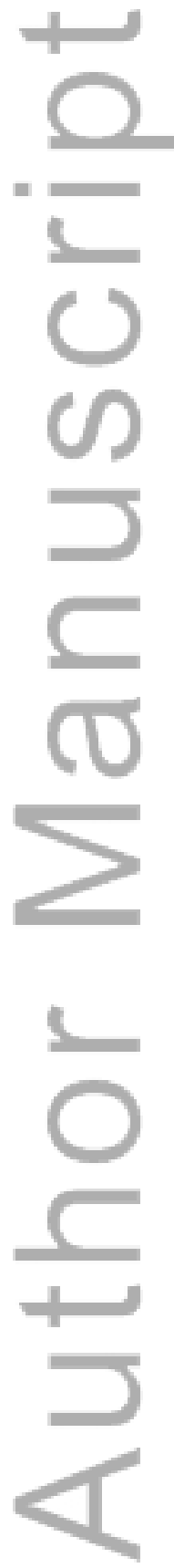

This article is protected by copyright. All rights reserved. 


\title{
Estimation of the Potential Eye and Tissue Donor Pool in an Australian Emergency Department
}

Short Running title: Improving eye and tissue donation in emergency

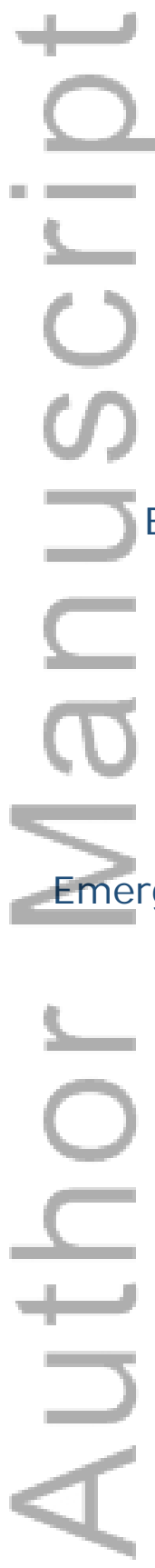

\author{
Authors: \\ Dr Damian Johnson MD, Bsc
}

Dr Martin Dutch

Emergency Physician and Medical Donation Specialist

BMedSci(Hons), MBBS(Hons), MPH\&TM, FACEM

A/Prof J onathan Knott MBBS PhD MClinEd FACEM

mergency Medicine Research Unit - Royal Melbourne Hospital 300 Grattan Street, Parkville VIC 3050

\author{
Martin.Dutch@mh.org.au \\ $+61413281864$ \\ Royal Melbourne Hospital \\ 300 Grattan Street, Parkville VIC 3050
}

Word Count: 2778

This article is protected by copyright. All rights reserved. 


\section{Abstract}

\section{Objective:}

Emergency Departments (EDs) have long been considered a potential source of eye and tissue donors, but no specific evidence to support this was identified in the Australian setting. This study aims to bridge that knowledge gap, by analysing medical and social histories of those who have died over a five year period so as to determine donation eligibility in this population.

\section{Methods:}

A retrospective audit was undertaken of all patients who died within the Royal Melbourne Hospital ED between 2010 and 2014. ED records, pharmacy records, and electronic medical histories were audited for the presence of eye and tissue donation exclusion criteria and the distribution of these criteria within the target population.

\section{Results:}

Over the five year period, of 326 deaths that occurred in the ED, one third was suitable for eye donation $(n=106)$ and one in seven $(n=45)$ for tissue donation.

Of the age appropriate patients, five criteria were identified that excluded up to $85 \%$ of the population not eligible to donate. These were: haematological malignancies, neurodegenerative conditions, nonhaematological malignancies, chronic renal failure, and eye disease. 


\section{Conclusion:}

This study has identified a large pool of potential eye and tissue donors; a pool mostly unrecognised by emergency clinicians.

An extensive list of exclusion criteria restricts donor potential. However, this study has identified that only five fundamentally limit donation in the ED population. Utilisation of this knowledge will allow for the development of clinical triggers that will improve identification, and increase realisation, of potential donors.

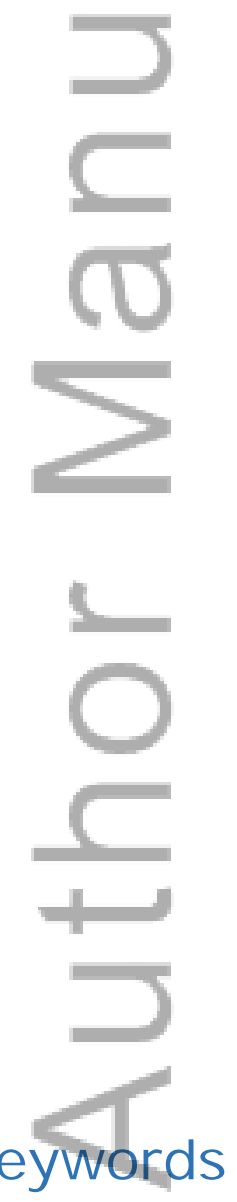

Eye, tissue, donation, donor potential, emergency department. 


\section{Introduction}

Last year in Australia there were 1,162 eye donors, and 331 deceased tissue donors. The donated tissues restored sight, improved quality of life, and in some instances saved the lives of over 3,000 Australians. Currently there are over 70 different human biologicals approved for use on the Australian Therapeutic Goods (TGA) Register, with donors capable of donating cardiovascular (valve, pericardium, vessel), musculoskeletal (tendon, meniscus, fascia, skin) and eye tissue (cornea and sclera). ${ }^{1}$ The demand for donated tissue continues to outstrip supply, limiting access to life-saving and life-transforming surgery. Increasing the number of eye and tissue donors is a key objective of the Australian Organ and Tissue Donation and Transplantation Authority. ${ }^{2}$

Not all deceased patients are medically suitable for eye or tissue donation. Unlike organ donation, where the patient pool is limited to ventilated patients, the eye and tissue donor can arise throughout the hospital, however the pool is limited by strict age (Eye $\leq 80 y e a r s$, tissue $\leq 70$ years), and medical and social history exclusion criteria (Table 1). These stricter criteria reflect a lower risk tolerance for disease transmission by the TGA. The list of exclusion criteria utilised in this study, published by the Australasian Transplant Coordinators Association, ${ }^{3}$ is not a universally authoritative source. The Therapeutic Goods Order No. $88^{4}$ is legally definitive in Australia and provides guidance for tissue and eye banks as a minimum standard that must be met for donation to 
occur, however individual banks currently have their own extended criteria.

Whilst medical exclusion involves direct diagnosis or detection of various illnesses or diseases, the social exclusion criteria involve behaviours or lifestyles that are associated with high risk of Human Immunodeficiency Virus (HIV), Hepatitis B or Hepatitis C. These include intravenous drug users, sex workers and those that have been incarcerated for greater than 72 hours in the 12 months prior to death. ${ }^{3}$

Deaths within Australian Emergency Departments (EDs) may constitute an important source of eye and tissue donors. Approximately 4,800 people die nationally per year in Australian EDs and, based on age criteria alone, half of these would be eligible for eye and cornea donation, and approximately a quarter for tissue donation. ${ }^{5,6}$

International experience shows that EDs represent a significant source of unrecognised potential eye and tissue donors. Whilst Australian EDs have been previously shown to represent a significant pool of unrecognised organ donors, the relative importance of the Australian eye and tissue ED donor pool remains unquantified. 
This study aims to bridge this gap in knowledge by analysis of those who have died in a large metropolitan Australian ED over a five year period, for presence of exclusion criteria, to determine the potential for donation in this population. This will be done through determination of the potential donor pool size and which exclusion criteria are the most important in limiting donor potential in this population

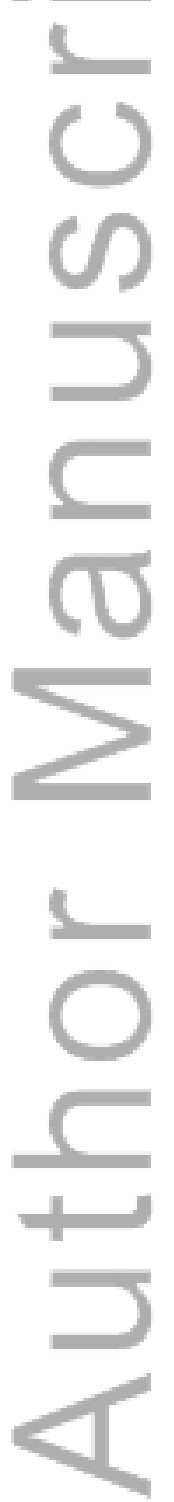




\section{Methods}

\section{Study Setting and Period}

A retrospective observational study encompassed all deaths that occurred within the Royal Melbourne Hospital (RMH) ED in the years 2010 to 2014. $\mathrm{RMH}$ is a tertiary hospital and major trauma centre, with more than 65,000 patients attending the ED annually. This includes over 900 major trauma cases and 16,000 patients arriving via ambulance. Approximately $40 \%$ are admitted and between 40 and 90 people die annually whilst in the ED.

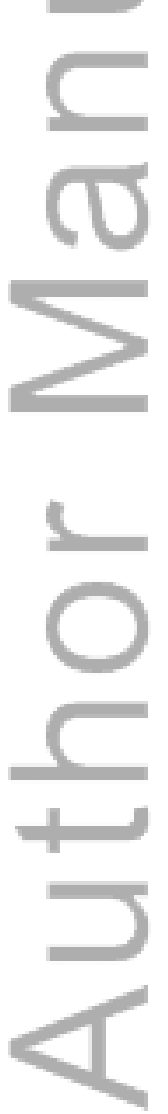




\section{Data collection}

Data was extracted from the ED electronic information system (Symphony ${ }^{\circledR}$, Ascribe, Bolton, United Kingdom). Details extracted included patient identification number, name, gender, birthdate, attendance date during which death occurred, and triage category. All patients with age greater than 80 years were excluded. Histories were audited for all medical or social exclusion criteria. The electronic medical record coding summary was searched using a method previously described by Galea. ${ }^{7}$ This summary dates back to 1993 in this institution. Hospital inpatient and outpatient pharmacy records were checked for drugs used to treat illnesses considered donor exclusion criteria according to the Australian Medicines Handbook. ${ }^{8}$ A condensed list of exclusion criteria (Table 1) was then applied to the data extracted from Symphony ${ }^{\circledR}$ and the International Coding for Diseases (ICD version 10) summary to determine presence of exclusion criteria for each patient (Appendix 3 details ICD-10 diagnoses present in the histories of those included in the study and considered applicable to criteria described in Table 1). Patients with no exclusion criteria for eye and/or tissue donation were considered as potential donors (Figure 1). The frequency of exclusion criteria was recorded. 
Whether the death was a Coroner's case, consideration of organ and tissue donation and time of death was also noted. "In-hours" was considered to be the hours that the RMH provides Donation Nurse Specialist Coordinators (8.00am until 10.00pm, Monday to Friday).

Patients in this study whose identity was unknown at time of death were followed up with the Coroner's Court of Victoria to determine age and to ensure that there were not medical histories under separate patient identification numbers.

The auditing of ED histories was done manually and 20 patients were chosen randomly and independently audited by all three investigators to compare the quality of data extraction. The three investigators found the same exclusion criteria during this audit, giving a high level of confidence that the ability to extract relevant data from the records by a single investigator would be consistent and reliable.

Of patients who were found to be eligible for eye or tissue donation, those who had transfusions within ED during their final presentation were identified. Haemodilution levels were calculated using the plasma dilution protocol from the Transplantation Society of Australia and New Zealand ${ }^{9}$ and average male and female weights in Australia. ${ }^{10}$ This allowed quantification of the potential impact on the donor pool. Haemodilution in excess of $50 \%$ prior to samples being taken for blood borne virus 
screening means these viruses cannot be accurately screened for and as such excludes a patient from donor eligibility.

\section{Data Analysis}

All data was collated into a single dataset. Analysis for trends in deaths over the five year study period was conducted using the Chi-Square test for trend. Descriptive statistics are used to describe the variables of interest.

The most commonly occurring exclusion criteria were manually applied to the population in a stepwise manner to determine the combination that maximally excluded unsuitable persons. It was the a priori intent to use only a small number (three to seven), with the eventual aim of the investigators to develop a clinical trigger or screening tool.

Approval was provided by the Melbourne Health Human Ethics and Research Committee (QA2014206).

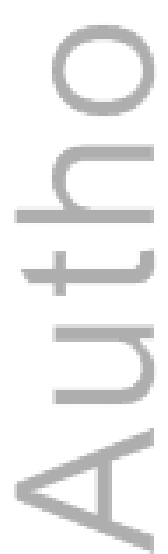




\section{Results}

During the five year period from 2010-2014, there were 301,879 ED attendances at the $\mathrm{RMH}$, with 326 deaths occurring (10.8 deaths per 10,000 attendances); $53 \%$ of attendances and $60 \%$ of deaths were male, median age at death was 81 years, and $89 \%$ of those that died were classified as Triage category 1 (requiring immediate assessment), or 2 (assessment within 10 minutes of arrival). ${ }^{11}$

\section{Potential Donor Pool}

One hundred and six patients were determined suitable for eye donation and 45 patients for tissue donation. All patients suitable for tissue donation were found to be suitable for eye donation in this population. Therefore, approximately one in three patients who died in the ED were suitable for eye donation and one in seven for tissue donation.

Approximately half of all deaths aged $\leq 80$ years were referred to the coroner, with approximately $60 \%(n=61)$ suitable for eye donation and $80 \%(n=36)$ suitable for tissue donation referred (Table 2$)$. Coronial review represents another opportunity to identify potential tissue donors in the State of Victoria. Conversely failure to identify 'non-coronial' potential donors represents a permanently lost opportunity. Half of all eye donation eligible patients $(n=52)$ and just under half of tissue donation eligible patients $(n=20)$ died in-hours. 
There was found to be a large variation in length of time spent in the ED from arrival until death was declared. The median time spent in the department for all deaths aged $\leq 80$ years was 110 minutes (Interquartile range $[I Q R]=36-241$ ). In those found suitable for eye and tissue donation the median times were 99 minutes $(I Q R=30-241)$ and 45 minutes $(I Q R=26-205)$ respectively.

The identities of eight patients whose identity was unknown at time of death by the hospital were obtained from the Coroner's Court of Victoria. None of these patients were found to have additional files held by the hospital.

\section{Exclusion criteria limiting donor potential}

Of 160 patients who died $\leq 80$ years, 54 were excluded due to medical or social exclusion criteria. The most common exclusion criteria were neurodegenerative conditions ( $n=26$ of $54,48 \%)$ and haematological malignancy $(n=18$ of $54,33 \%)$. In patients not excluded by these two criteria, eye disease was the next most important criteria. Screening for neurodegenerative conditions, haematological malignancy, and eye disease would identify $85 \%$ of patients ineligible for eye donation (Figure 3).

Of 94 patients who died $\leq 70$ years, 49 were excluded due to medical or social exclusion criteria. The most important exclusion criterion was nonhaematological malignancy. For the remainder, the next most important criteria were chronic renal failure and neurodegenerative conditions. 
Screening for these three criteria would identify $75 \%$ of patients ineligible for tissue donation. Screening for high risk of blood-borne virus as well identifies $80 \%$ of ineligible patients (Figure 3 ).

In patients' $\leq 80$ years of age at death, three exclusion criteria excluded $85 \%$ of unsuitable eye donors. In patients' $\leq 70$ years at death, a further two"exclusion criteria excluded $80 \%$ of unsuitable tissue donors. These five criteria are: neurodegenerative conditions, haematological malignancy, non-haematological malignancy, chronic renal failure, and eye disease (Figure 3 ).

There was a significant trend for an increasing proportion of age eligible patients being excluded from eye and tissue donation, over the study period (Chi Square Test for Trend: Eye Slope $-0.10, p=0.02$, Tissue Slope $-0.12, p=0.03$ ). Significant trends to increasing documentation of contraindications for neurodegenerative conditions $(p=0.05)$ in hospital coding and haematological malignancies in Symphony records were found $(p=<0.04)$.

There was significant variation in the frequency in which the various exclusion criteria were present in this population. While important criteria such as neurodegenerative conditions and malignancies were found often, there were four eye and six tissue exclusion criteria not recorded in this population. There were 43 patients excluded from eye donation and 24 patients excluded from tissue donation with a single exclusion criterion. A number of criteria were identified that had low incidence in this population 
(e.g. amyloidosis). These criteria occur infrequently but are important as some patients were excluded solely on these criteria (Figure 2). No patients were found to have received drugs used for exclusion criteria that had not been found in their ED records or ICD coding summary.

The records of seven patients otherwise considered suitable for donation were reviewed for transfusion volumes. Four patients were determined to have received transfusion volumes that would have resulted in greater than $50 \%$ haemodilution. The records of a further two patients where haemodilution may have limited donation potential could not be located and for these patients haemodilution levels could not be calculated.

Consideration of eye and tissue donation was documented only 15 times in the records of the 160 patients who died $\leq 80(9 \%)$. Of the 15 patients where consideration was documented, 11 were identified as medically suitable and four as medically unsuitable for donation. In each of the four cases where the treating doctor determined the patient unsuitable for donation, exclusion criteria were found in the patients' history. In addition, another patient was reviewed for suitability for organ donation, however was not considered for eye or tissue donation, following the audit, this patient was considered suitable for both eye and tissue donation. 


\section{Discussion}

The study has identified a large pool of potential eye and tissue donors, yet a low incidence of consideration of donation by doctors in the department was documented.

\section{Validity of donor pool estimate}

This study used similar methodologies to previously published international studies in order to quantify the donor pool. These included age criteria, patient discharge ICD coding, and ED clinical note review. A number of novel strategies, including post mortem identification of name, medical record review, pharmacy record review, and haemodilution calculations were conducted to bolster internal validity.

\section{Potential Emergency Department donor pool}

Estimation of the raw number of potential donors from any pool is derived from the product of the donor pool size, the identification of potential donor rate, and the consent rate for donation. Nationally, Donatelife hospitals have an identification rate of $97 \%$, and a consent rate of $61 \%$ for organ donation. ${ }^{12}$ This consent rate is similar to previously published corneal consent rates at our hospital. ${ }^{13}$ Assuming the same consent rate was achieved in the potential pool of donors identified in this study, 65 eye donors and 27 tissue donors could have been expected across the five years. ${ }^{14}$ 
In 2013, more than 4,800 Australians died in an ED. ${ }^{6}$ Of these deaths, it is expected that 1,260 met age eligibility requirements to be eye and tissue donors and a further 1,100 met age criteria to be isolated eye donors. ${ }^{15}$ If patient profiles across Australian EDs were found to be similar to the study site, there are approximately 1,500 potential eye and 600 potential tissue donors annually in Australian EDs. Applying a consent rate of $61 \%$ would mean potentially 953 eye and 368 tissue donors annually. This results nationally in an over $80 \%$ increase in total eye donors, and a $110 \%$ increase in tissues donors. While there is likely some overlap between the current donor pool and the potential pool sourced through EDs this cannot currently be accurately estimated.

Even with expected variations in hospital demographics, and potentially different consent rates, the magnitude of donors estimated by this study indicates there is likely a significant pool of currently unrecognised donors within Australian EDs.

\section{I mproving identification of the potential donor pool}

Within Australia, failure to identify and refer potential donors is a major factor in low population wide donation rates. ${ }^{16}$

International studies have demonstrated that simplified referral processes and the use of highly motivated and trained staff are effective, while the use of legislative changes, forms, and expecting doctors to consider donation without aids to remind and simplify identification are ineffective. ${ }^{13,17-19}$ 
To increase potential eye and tissue donor rates, the Australian Government's Organ and Tissue Authority has several strategic objectives, including the implementation of end of life prompts for donor identification and referral of all potential tissue donors in EDs over the next few years.

This study has identified a small number of screening criteria that identify the majority of medically non-suitable donors. These five criteria (Table 1a) when used to screen for both eye and tissue donation have similar sensitivity to screening for six different criteria when screening the same population for eye and tissue donation separately (Figure 3). The utilisation of these five criteria may go some way to illuminate the path of novel automated referral processes.

Although there was a lack of documented consideration of donation, the failure to document may indicate doctors are not considering donation at all. It is possible that some patients were considered for donation eligibility without it being documented. If this occurred, the accuracy with which suitability for donation was identified is unknown. The use of an automatic clinical trigger, which screens all patients who die, would eliminate these missed opportunities and allow for correct identification of patients unsuitable for donation. 


\section{Limitations and potential impact on true donor pool}

As a single-site, retrospective study, the ability to estimate the true potential donor pool in Australian EDs is limited. There is a possible over estimation of potential donors based on incomplete medical histories held by the hospital. Some patients had very extensive records held by the hospital, others died during their first attendance such that little was known or recorded in their medical histories. An attempt to mitigate this by gaining further information regarding cause of death and any antecedent causes from Births, Deaths and Marriages Victoria was made, however this information was not available.

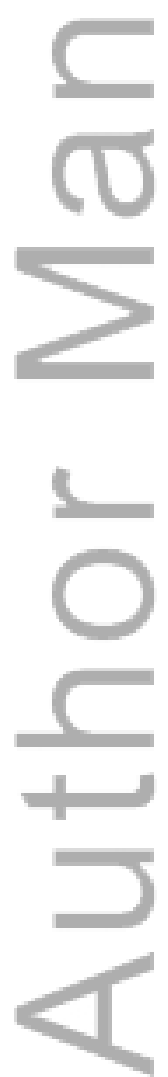




\section{Conclusion:}

This study has identified a large pool of potential eye and tissue donors. Despite $76 \%$ of Australians being supportive of eye and tissue donation, and one quarter registering their intent on the national register, these potential donors appear to be largely unrecognised by emergency clinicians.

Whilst an extensive list of exclusion criteria restrict donor potential, this study has identified that only five fundamentally limit donation in the ED population. The utilisation of this knowledge will allow for the development of clinical triggers that will improve identification, and increase realisation, of potential donors.

The recognition and utilisation of this potential donor pool must improve so that the mismatch between donors and those awaiting transplantation can be reduced, allowing a greater number to have their quality of life improved through transplantation of eye or tissue. 


\section{Abbreviations:}

Emergency Department - ED

International Classification of Diseases version 10 (ICD-10)

Interquartile Range - IQR

Royal Melbourne Hospital - RMH

Therapeutic Goods Association - TGA

Acknowledgements:

The authors would like to acknowledge assistance from the members of the Royal Melbourne Hospital Emergency Department, DonateLife Victoria, the Donor Tissue Bank of Victoria and the Lions Eye donation Service
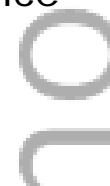

Disclosure:

Dr Martin Dutch is fractionally employed as a Medical Donation Specialist by DonateLife Victoria. 


\section{Tables:}

\section{Table 1 I mportant exclusion criteria identified in this}

population (a) and a summary of current extended exclusion criteria for eye and tissue donation (b) ${ }^{3}$

a)

Exclusion criteria most important in the Emergency Department population:

Neurodegenerative Conditions

Haematological malignancies

Non-haematological malignancies

Chronic Renal Failure

Eye Disease

b)

Exclusion criteria for eye and tissue donation

Active fungaemia

Active chlamydia or syphilis

Active tuberculosis

Active viraemia

Blood-borne virus (high risk)

Creutzfeldt-Jakob Disease (or prion disease any type) or CJD risk (blood relatives of persons diagnosed with $C J D$ of any type, recipients of human pituitary-derived hormones from 1963 to 1985, recipient of human-derived dura mater tissue at any time )

CNS infection (meningitis or encephalitis (active, viral or of unknown origin)

Demyelinating disorders (multiple sclerosis, Guillian-Barre Syndrome )

Haematological malignancy (Hodgkin's disease, lymphoma, lymphomatoid granulomatosis, lymphosarcoma, myeloma, myeloproliferative disease, polycythemia vera - primary)

Human immunodeficiency Virus, Human T-cell lymphotrophic virus

Neurodegenerative conditions (Parkinson's disease, Huntington's Disease, Motor Neurone Disease, Progressive multifocal encephalopathy, subacute sclerosing panencephalitis, Reye's Syndrome)

Organ or tissue recipient (a solid organ recipient within the last 12 months, ever recipient of human dura mater, ever recipient of viable xenotransplant (cells or tissue), a solid organ recipient in England, Scotland, Wales, Northern Ireland or the Isle of Man, a recipient of human pituitary derived hormone)

Tropical disease (malaria (active), leprosy (active), rabies, typhoid, chickungunya, malaria risk)

Viral hepatitis

Exclusion criteria for tissue donation only

Inflammatory/Vasculitides (fibromyalgia, polymyocitis, ankylosing spondylitis, Systemic Lupus Erythematosus, ulcerative colitis or Crohn's disease)

This article is protected by copyright. All rights reserved. 
Chronic renal failure

Myasthenia gravis

Non-haematological malignancies (other than basal cell carcinoma, cervical carcinoma in situ, primary brain tumour)

Systemic infection or severe localised infection

Amyloidosis

Muscular dystrophy

Exclusion criteria for eye donation only

Eye disease

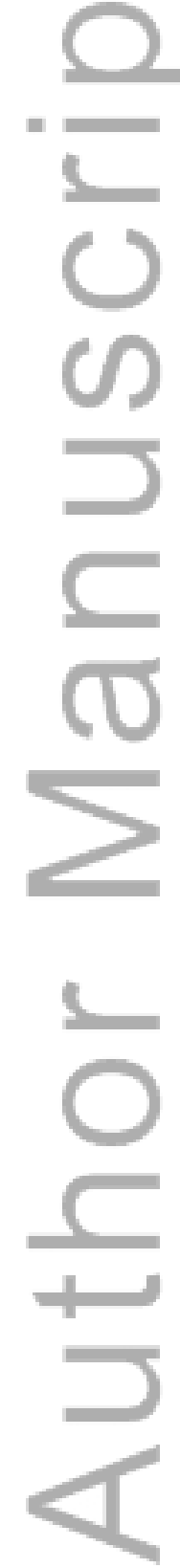

This article is protected by copyright. All rights reserved. 
Table 2 Summary of all deaths, potential tissue and eye donors from ED attendances 2010-14

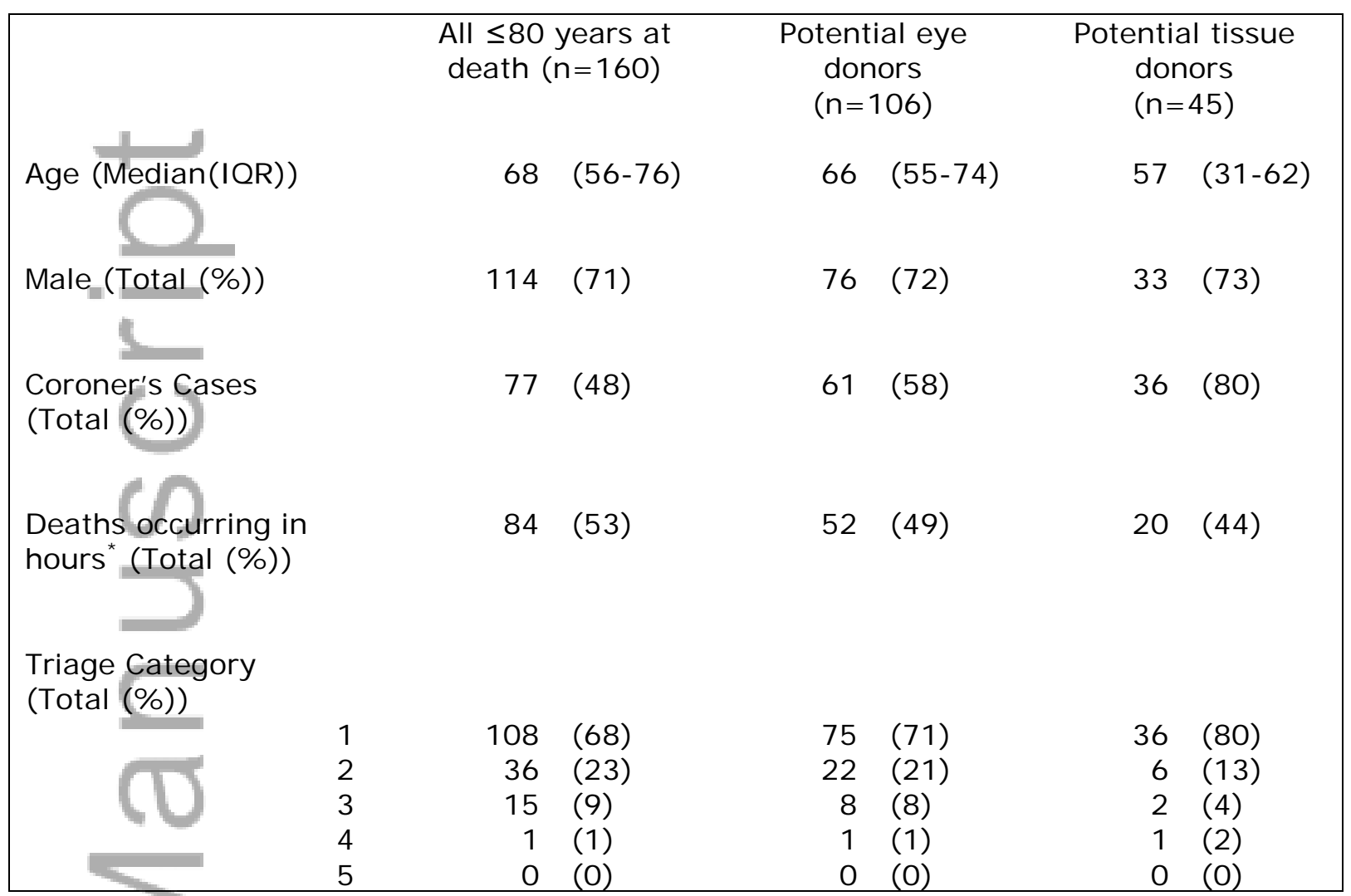

* "In-hours" was considered to be during the hours that the RMH staffs Donation Nurse Specialist Coordinators (8.00am until 10.00pm, Monday to Friday).

** Triage Categories: Patients that require treatment and assessment: 1 - immediately and simultaneously, 2within 10 minutes of arrival (and often simultaneously), 3 - within 30 minutes of arrival, 4 - within 60 minutes of arrival, 5 - within 120 minutes of arrival. ${ }^{11}$

This article is protected by copyright. All rights reserved. 
Table 3 Total deaths per year, and the number of these patients that were determined to be suitable for eye and tissue donation.

\begin{tabular}{|c|c|c|c|c|}
\hline \multicolumn{2}{|c|}{ Deaths $\leq 80$ years ${ }^{*}$} & \multicolumn{2}{|c|}{ Deaths $\leq 70$ years ${ }^{*}$} & All ED deaths \\
\hline Subtotal & $\begin{array}{l}\text { Eligible for } \\
\text { eye donation } \\
\text { (\%) }\end{array}$ & Subtotal & $\begin{array}{c}\text { Eligible for } \\
\text { tissue } \\
\text { donation (\%) }\end{array}$ & Total \\
\hline 2010 & $37 \quad(88)$ & 20 & $13(65)$ & 83 \\
\hline 2011 & 19 (73) & 13 & $8 \quad(62)$ & 58 \\
\hline 2012 & $15 \quad(58)$ & 15 & $9 \quad(60)$ & 49 \\
\hline 2013 & $24 \quad(65)$ & 26 & $9 \quad(35)$ & 63 \\
\hline 2014 & 11 (37) & 20 & $6 \quad(30)$ & 73 \\
\hline Total: 161 & $106 \quad(66)$ & 94 & $45 \quad(48)$ & 326 \\
\hline
\end{tabular}

* "Deaths $\leq 80$ years" also includes deaths $\leq 70$ years (all deaths suitable by age for eye donation)

This article is protected by copyright. All rights reserved. 


\section{Figures:}

Figure 1 Screening algorithm for consideration of eye and tissue donation, with the number of patients from the Royal Melbourne Hospital Emergency Department population from 2010-2014 included at each stage of analysis.

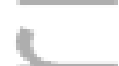

Figure 2 Exclusion criteria identified in patients age appropriate at death for a) eye and b) tissue donation (These groups are not mutually exclusive, with all patients age appropriate at death for tissue donation also age appropriate for eye donation).

* denotes exclusion criteria applicable to both.

CNS = Central nervous system, HIV or HTLV= Human immunodeficiency syndrome, Human T-cell lymphotrophic virus, CJD or CJR risk = Creutzfeldt-Jakob Disease or prion disease any type. Refer to Table 1 for further detail on exclusion criteria.

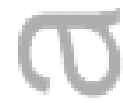

Figure 3

Stepwise exclusion of ineligible patients from eye and tissue donation

A shows stepwise exclusion from eye donation, B from tissue donation, considered in isoltation

C-D shows stepwise exclusion of ineligible patients from eye (C) and tissue (D) donation using a composite model taking advantage of shared exclusion criteria.

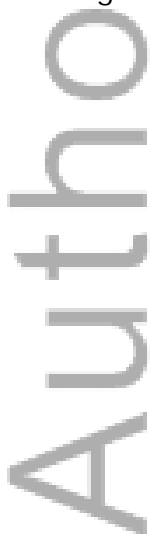

This article is protected by copyright. All rights reserved. 


\section{References:}

1. ANZOD Eye and Tissue Data 2014 Year End Report. Australia: Australia and New Zealand Organ Donation Registry; 19 May 2015 [Updated 19 May 2015; cited 5 Nov 2015]. Available from: http://www.anzdata.org.au/anzod/updates/ANZOD 2014AU TissueDataReport 20150519.pdf (Accessed 21 Nov 2015).

2. Organ and tissue donation for transplantation in Australia 2014-2018 Strategic plan. Australia: Australia Government Organ and Tissue Authority; 2014 [Updated 30 Jun 2015; cited 5 Nov 2015]. Available from: http://www.donatelife.gov.au/sites/default/files/201418\%20Organ\%20and\%20tissue\%20donation\%20for\%20transplantation\%20in\%20Australia\%20Strate gic\%20Plan.pdf (Accessed 21 Nov 2015).

3. National Guidelines for organ and tissue donation 4th Edition [Internet]. Australia: Australasian Transplant Coordinators Association Incorporated, 2008 [Updated 24 Jul 2014, cited 28 Sep 2014]. available from http://www.atca.org.au/files/F.pdf (Accessed 21 Nov 2015).

4. Therapeutic Goods Order No. 88 - Standards for donor selection, testing, and minimising infectious disease transmission via therapeutic goods that are human blood and blood components, human tissues and human cellular therapy products. Australia. Australian Government Department of Health and Ageing - Therapeutic Goods Administration; 20 May 2013 [cited 3 Mar 2016]. Available from: https://www.comlaw.gov.au/Details/F2013L00854 (Accessed 3 Mar 2016).

5. Australian Hospital Statistics 2012-13 [Internet]. Canberra: Australian Institute of Health and Welfare; 30 Apr 2014 [cited 18 Mar 2015]. Available from: http://www.aihw.gov.au/publicationdetail/?id=60129546922A (Accessed 21 Nov 2015).

6. Australian Hospital Statistics 2012-13: emergency department care [Internet]. Canberra: Australian Institute of Health and Welfare; 18 Oct 2013 [cited 2015 Mar 18]. Available from: http://www.aihw.gov.au/publication-detail/?id=60129544913 (Accessed 21 Nov 2015).

7. Galea G. Estimating the potential of tissue donation in Scotland. Scottish medical journal. 2012;57(4):185-90.

8. Australian Medicines Handbook 2015. 2015 edition. Australia: AMH; 2015.

9. Donor referrals protocols [Internet]. Australia: Australasian Transplant Coordinators

Association [Updated 28 Sep 2014, cited 18 June 2015]. Available from:

https://www.tsanz.com.au/downloads/Protocols Appendix1.pdf (Accessed 21 Nov 2015).

10. 4338.0 - Profiles of Health, Australia, 2011-13. [Internet]. Australia: Australian Bureau of statistics; 10 Oct 2012 [Updated 29 Oct 2012, cited 18 June 2015]. Available from: http://www.abs.gov.au/ausstats/abs@.nsf/Lookup/by\%20Subject/4338.0 201113 Main\%20Features $\sim$ Height\%20and\%20weight 21 (Accessed 21 Nov 2015).

11. Guidelines on the Implementation of the Australasian Triage Scale in Emergency Department [Internet]. Melbourne: Australasian College of Emergency Medicine. 2000 Nov [updated 2013 Nov; cited 201526 Oct] Available from: http://www.acem.org.au/getattachment/d19d5ad3-e1f4-4e4fbf83-7e09cae27d76/G24-Implementation-of-the-Australasian-Triage-Scal.aspx (Accessed 21 Nov 2015).

12. Organ and Tissue Authority Donation and Transplantation Performance Report for 2014 [Internet]. Australia: Australia Government Organ and Tissue Authority; 10 Feb 2015 [cited 18 June 2015]. Available from:

http://www.donatelife.gov.au/sites/default/files/OTA\%202014\%20Performance\%20Report\%20Jan\% 202015\%20FINAL.pdf (Accessed 21 Nov 2015).

13. Chopra GK, De Vincentis F, Kaufman D, Collie D. Effective corneal retrieval in a general hospital. The Royal Melbourne Hospital Eye Bank. Australian and New Zealand journal of ophthalmology. 1993;21(4):251-5.

14. Michael GE, O'Connor RE. The importance of emergency medicine in organ donation: successful donation is more likely when potential donors are referred from the emergency department. Academic emergency medicine : official journal of the Society for Academic Emergency Medicine. 2009;16(9):850-8. 
15. 3101.0 - Australian Demographic Statistics, Jun 2012 [Internet]. Canberra: Australian Bureau of Statistics; 18 Dec 2012 [Updated 27 Mar 2013, cited 18 Mar 2015]. Available:

http://www.abs.gov.au/AUSSTATS/abs@.nsf/allprimarymainfeatures/33970B13F1DF7F56CA257B3B 00117AA2?opendocument (Accessed 21 Nov 2015).

16. Marck CH, Weiland TJ, Hickey BB, Jelinek GA. Assessing Barriers to Organ and Tissue Donation in Emergency Departments: FINAL REPORT to Commonwealth of Australia, Organ and Tissue Authority. Melbourne: Emergency Practice Innovation Centre, St Vincent's Hospital Melbourne; 2011.

17. DonateLife Network [Internet]. Australia: Organ and Tissue Authority; 2014 [Cited 22 Sep 2014]. Available from: http://www.donatelife.gov.au/about-us/donatelife-network (Accessed 21 Nov 2015).

18. Lee K, Boimer C, Hershenfeld S, Sharpen L, Slomovic AR. Sustainability of Routine Notification and Request legislation on eye bank tissue supply and corneal transplantation wait times in Canada. Canadian journal of ophthalmology Journal canadien d'ophtalmologie. 2011;46(5):381-5.

19. Marck CH, Jelinek GA, Neate SL, Dwyer BM, Hickey BB, Weiland TJ. Resource barriers to the facilitation of organ and tissue donation reported by Australian emergency clinicians. Australian health review : a publication of the Australian Hospital Association. 2013;37(1):60-5.

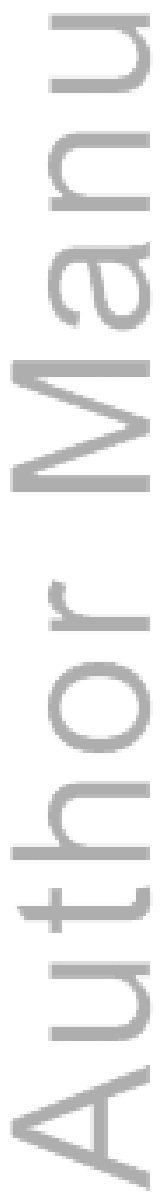

This article is protected by copyright. All rights reserved. 


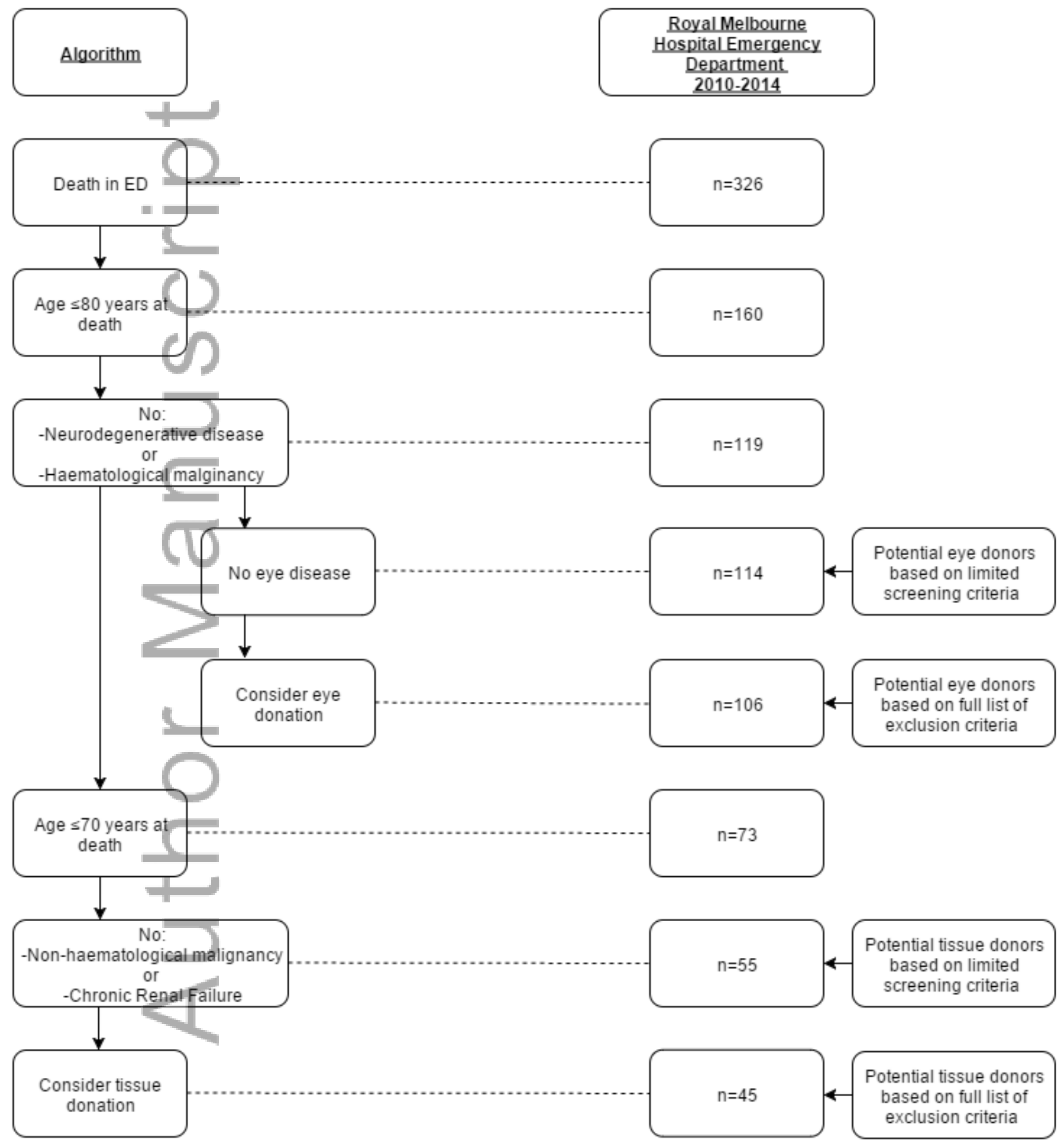

EMM_12576_f1.tif

This article is protected by copyright. All rights reserved. 

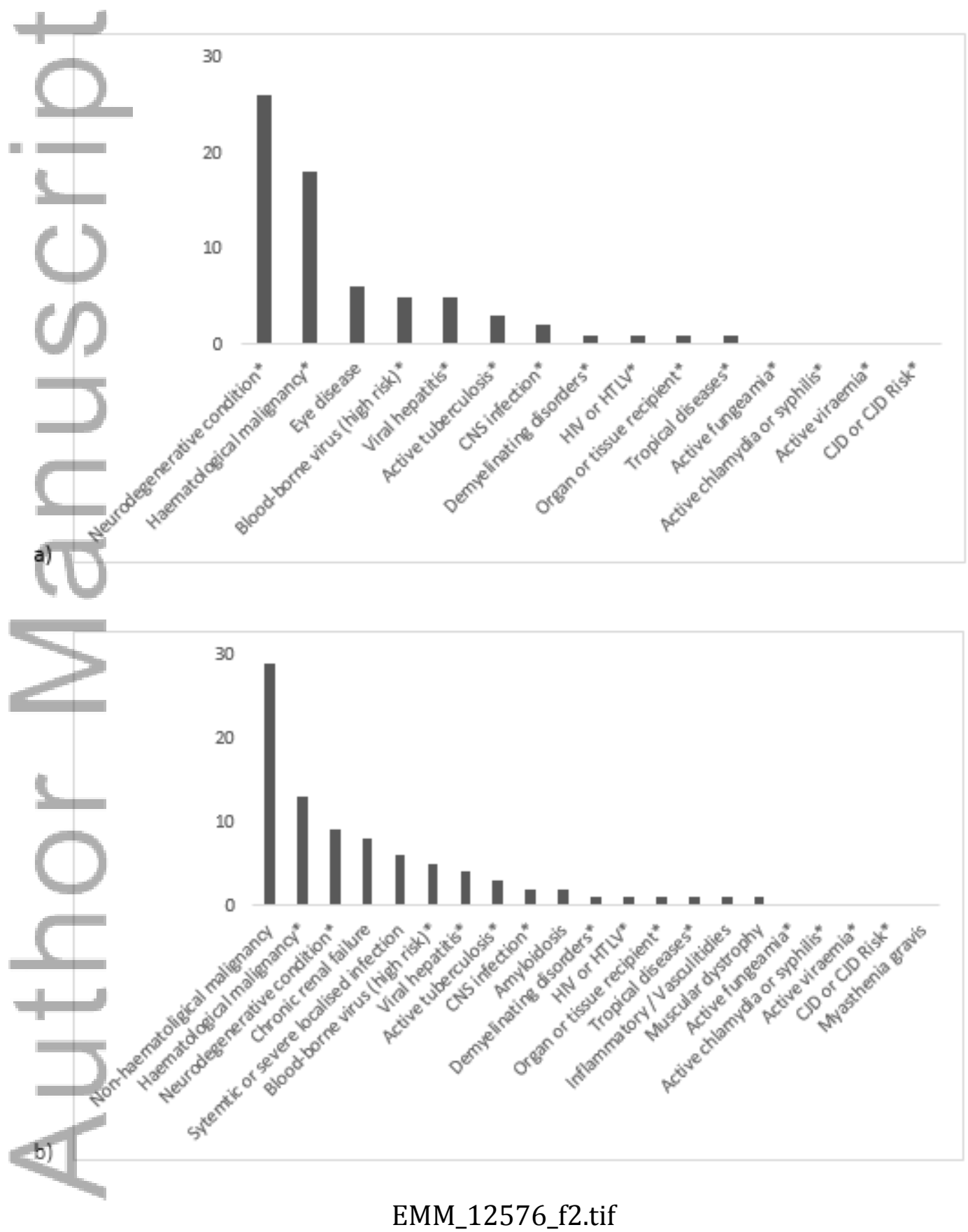

This article is protected by copyright. All rights reserved. 


\section{University Library}

\section{- M M N E R VA A gateway to Melbourne's research publications}

Minerva Access is the Institutional Repository of The University of Melbourne

Author/s:

Johnson, D;Dutch, M;Knott, J

Title:

Estimation of the potential eye and tissue donor pool in an Australian emergency department

Date:

2016-06-01

Citation:

Johnson, D., Dutch, M. \& Knott, J. (2016). Estimation of the potential eye and tissue donor pool in an Australian emergency department. EMERGENCY MEDICINE AUSTRALASIA, 28 (3), pp.300-306. https://doi.org/10.1111/1742-6723.12576.

Persistent Link:

http://hdl.handle.net/11343/291164 